Article

\title{
Study of Social and Environmental Needs for the Selection of Sustainable Criteria in the Procurement of Public Works
}

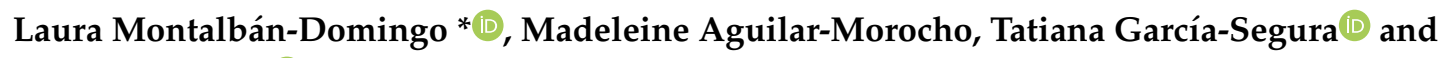 \\ Eugenio Pellicer(D) \\ Construction Project Management Research Group, Universitat Politècnica de València, Camino de Vera s/n, \\ 46022 Valencia, Spain; maag4@cam.upv.es (M.A.-M.); tagarse@cam.upv.es (T.G.-S.); pellicer@upv.es (E.P.) \\ * Correspondence: laumondo@upv.es; Tel.: +34-96-387-7000
}

Received: 3 September 2020; Accepted: 11 September 2020; Published: 19 September 2020

\begin{abstract}
Fostering sustainability in the construction industry has been claimed; however, important barriers are hindering its implementation in public procurement. The main reason is the lack of knowledge about what sustainability criteria should be included and the high level of subjectivity in the definition of their level of importance. Both aspects should be addressed depending on the specific context of each country. Therefore, the aim of this research focused on identifying the sustainability shortcomings that exist in each European Union country in order to determine the level of importance of each sustainability category. Five environmental categories and eight social categories were established, and, to assess the sustainability performance of the 28 European countries, 42 national indicators were selected and the Promethee method was undertaken to rank the countries. Finally, through a cluster analysis, two groups of countries were identified. The first group consisted of the most economically developed European Union countries. These countries need to focus mainly on the environmental performance. However, the second group needs to make an effort in social sustainability at the same time, which controls their environmental performance. This research provides guidance on the decision-making with regard to the inclusion of sustainability in public procurement of the construction industry.
\end{abstract}

Keywords: multicriteria analysis; public procurement; environmental criteria; social criteria; Promethee; sustainability

\section{Introduction}

Civil engineering projects are necessary for the development of society, especially for the economic development of countries [1]. However, construction is a critical industry with important effects on the environment, economy, and society [2,3]. For that reason, the need to ensure sustainable development in this industry has been demanded [4]. Developing new infrastructures and maintaining the existing ones is sustainable when the market demands in terms of social, environmental, and economic sustainability are satisfied [5].

Public procurement has been claimed as the best alternative to influence the market in terms of sustainable production and consumption since it represents large volumes of public spending each year [6]. In this regard, in the European Union (EU henceforth), the legal evolution from 2004 to 2014 has opened an opportunity to contribute to different social and environmental objectives [7]. Firstly, green public procurement was boosted as a key instrument to reduce the environmental impact of organizations [8,9]. The 2004 directives (Directive 2004/18/EC and Directive 2004/17/EC) explicitly stated that environmental criteria could be considered in procurement procedures as obligatory technical 
specifications for the product or service or as award criteria [9]. Subsequently, social considerations became relevant in public procurement [10]. The 2014 directives (Directive 2014/24/EU, Directive 2014/25/EU, and Directive 2014/23/EU) promoted a different approach in both the employment context and in supplier diversity. New and powerful terms were presented to go beyond and providing broader social benefits [11,12]. On the one hand, the directives increased the scope for contracting authorities to include social and environmental considerations in the design and execution of public tenders and, on the other hand, gave the member states some freedom to define national mechanisms to include social considerations in public procurement [10,12]. In this regard, Directive 2014/24/EU fosters contracting authorities to determine the most economically advantageous tender using social and environmental life cycle costing approach. Additionally, articles 67 and 68 of this directive set out a nonexhaustive list of possible award criteria, which includes environmental and social aspects. The aim of this list was to encourage contracting authorities to choose social and environmental award criteria in order to exploit the potential of public procurement to achieve the objectives of the Europe 2020 strategy [13].

In the construction industry, the design and construction of civil engineering projects are carried out mainly through public procurement procedures [2]. For that reason, the role of public procurement to promote the inclusion of sustainability has been proclaimed as a key element to favor the transformation of the construction sector towards sustainable construction [4]. However, currently, there are important barriers that prevent the effective inclusion of social and environmental criteria in procurement $[8,14,15]$. This mainly happens because of the lack of knowledge regarding the sustainability criteria that should be included in tenders and how these should be included to ensure their objective evaluation $[16,17]$. In addition, the level of importance assigned to these types of criteria in bidding processes is generally defined based on the intuition of public administration personnel and, thus, with a high level of subjectivity $[4,15]$. This is because there is an absence of a clear methodology that helps procurers to decide the criteria that should be considered in the bidding processes, as well as to assist in having an orientation regarding the weights that should be assigned to each one of them $[15,18]$. In this regard, a quantitative analysis of the sustainable development of different countries can help to understand the constraints and to propose specific measures to enhance sustainability [19]. In fact, Montalbán-Domingo et al. [14] highlighted the importance of taking into account the specific context of each country for both deciding the sustainable criteria to be included in public procurement and establishing the level of importance of these criteria in procurement procedures.

National indicators can be used to assess the sustainable performance of counties [20]. A large number of organizations have worked to define national indicators for different social and environmental topics [21]. The proof is that the World Bank's databank collects more than 1000 indicators defined by more than 70 different organizations, the United Nations established more than 200 indicators to assess the sustainable development goals, and the EU Sustainable Development Strategy defined more than 130 indicators to monitor and assess the progress towards the sustainable development [22]. Previous authors $[14,16]$ have used national indicators to carry out comparative analyses of the sustainable performances of the EU Member States. Phillis et al. [23] evaluated the sustainable development of 106 cities in different countries and Widomski et al. [24] compared the sustainable development of Lublin and Poland with other EU countries. One of the main conclusions of these works was the importance of using multivariate data mining techniques for analysis of sustainable performance [19]. In this regard, the use of national indicators, joined with multicriteria decision (MCD) techniques, can be used for identifying the sustainable needs of each country [22]. In addition, this approach can assist procurers in their decision-making with respect to the sustainability criteria to be considered and the level of importance to be assigned to each of them [16].

Therefore, the aim of this paper was to identify the sustainable deficiencies of each European Union country (EU country henceforth) through a cross-country comparison. The use of Promethee was proposed for performing an objective measurement and assessment of sustainability performance. This way, the paper is organized as follows: Section 2 establishes the environmental and social criteria 
that should be included in public procurement of the construction industry; Section 3 details the method; Section 4 collects the results; a discussion of the research findings is comprised in Section 5; and, finally, Section 6 presents the concluding remarks, limitations, and future work.

\section{Environmental and Social Criteria}

In the construction industry, environmental sustainability can be understood as the protection of natural resources in order to reduce energy and water consumption, using renewable resources, and minimizing pollution [25]. Measuring environmental sustainability requires a careful evaluation of a wide range of criteria [26]. Initially, the inclusion of environmental criteria in public procurement focused only on controlling pollution. Subsequently, there was an evolution, and criteria such as recycling, reusing, waste disposal during production, energy use, the use of harmful substances, $\mathrm{CO}_{2}$ emissions, work environment, noise control, and environmental management systems in the contractor's organization were included [27-30]. However, although environmental sustainability has emerged as an important field, this term has been misinterpreted in public procurement $[8,30]$, and a limited number of environmental aspects has been considered in many instances [31].

Therefore, in order to clarify the environmental criteria that should be considered to assess the environmental performance in construction tendering documents, a deeper investigation into environmental sustainability was performed. This study reviewed guides, reports, books, sustainability certification systems, and scientific literature in order to determine the environmental categories that should be considered in public procurement of the construction industry. Environmental categories were grouped using the affinity diagram technique [32] into five categories: energy, emissions, waste, water, and flora and fauna. Fourteen subcategories were established to explain these five categories. Table 1 gathers a brief description of each environmental subcategory.

Table 1. Environmental categories and subcategories.

\begin{tabular}{|c|c|c|c|}
\hline Category & Subcategory & Source & Justification and Explanation \\
\hline \multirow[t]{2}{*}{ Energy } & $\begin{array}{l}\text { Minimization and control of } \\
\text { energy consumption }\end{array}$ & [33-38] & $\begin{array}{l}\text { Improving energy efficiency is important to reduce } \\
\text { the dependency on energy imports and to reduce } \\
\text { pollution. To that end, the literature highlights the } \\
\text { use of energy monitoring systems and getting } \\
\text { energy performance certificates at the project level. }\end{array}$ \\
\hline & Use of renewable energies & {$[18,26,38-40]$} & $\begin{array}{l}\text { The generation of energy from fossil fuels produces } \\
\text { greenhouse gas emissions, resource depletion, } \\
\text { emissions of air pollutants, ocean acidification, and } \\
\text { water pollution. }\end{array}$ \\
\hline \multirow[t]{2}{*}{ Emissions } & $\begin{array}{l}\text { Reducing and control the } \\
\text { emissions of polluting gases }\end{array}$ & {$[33-35,38,40,41]$} & $\begin{array}{l}\text { Emissions of greenhouse gases contribute to } \\
\text { multiple global climate change impacts and } \\
\text { exacerbate oceanic acidification. }\end{array}$ \\
\hline & $\begin{array}{l}\text { Minimizing the emissions of } \\
\text { dust and other particles }\end{array}$ & {$[33,34,42,43]$} & $\begin{array}{l}\text { Construction dust is one of the main sources of air } \\
\text { emissions during an infrastructure's lifecycle. }\end{array}$ \\
\hline \multirow{4}{*}{ Waste } & $\begin{array}{l}\text { Construction/demolition } \\
\text { waste management and } \\
\text { disposal }\end{array}$ & {$[26,33,34,44]$} & $\begin{array}{c}\text { Proper waste management is essential to guarantee } \\
\text { lower rates of sending waste to landfill, placing } \\
\text { less strain on natural. }\end{array}$ \\
\hline & $\begin{array}{l}\text { Reduction of pollution } \\
\text { caused by the spillage }\end{array}$ & {$[38,44-46]$} & $\begin{array}{l}\text { In the construction industry, the reduction of } \\
\text { spillage through conservation measures is } \\
\text { demanded. An example is the creation of } \\
\text { settlement lagoons intended to protect } \\
\text { watercourses from pollution by containment of } \\
\text { spillages. }\end{array}$ \\
\hline & Recycling and reusing & {$[12,29,33,36,41]$} & $\begin{array}{l}\text { Recycled and reused materials have been } \\
\text { recognized as making an important contribution to } \\
\text { reducing landfill and conserving nonrenewable } \\
\text { resources. }\end{array}$ \\
\hline & $\begin{array}{l}\text { Minimizing waste } \\
\text { generation }\end{array}$ & {$[35,37,44,47]$} & $\begin{array}{l}\text { Waste has an important part to play in reducing } \\
\text { carbon dioxide emissions. }\end{array}$ \\
\hline
\end{tabular}


Table 1. Cont.

\begin{tabular}{|c|c|c|c|}
\hline Category & Subcategory & Source & Justification and Explanation \\
\hline \multirow{3}{*}{ Water } & $\begin{array}{l}\text { Water quality protection and } \\
\text { control }\end{array}$ & {$[18,36,39]$} & $\begin{array}{l}\text { Water quality in streams can be affected by the } \\
\text { construction. Having a hydro geological protection } \\
\text { system and storm water management is essential } \\
\text { during the construction works. }\end{array}$ \\
\hline & $\begin{array}{l}\text { Treatment and restoration } \\
\text { measures }\end{array}$ & {$[38,48,49]$} & $\begin{array}{l}\text { Pollutant removal can be an important component } \\
\text { of protecting stream water quality. }\end{array}$ \\
\hline & $\begin{array}{l}\text { Minimizing water } \\
\text { consumption }\end{array}$ & {$[38,45,50]$} & $\begin{array}{l}\text { It is critical that infrastructure projects reduce } \\
\text { overall water use, particularly potable water. One } \\
\text { of the main impacts of civil engineering works on } \\
\text { the water can be consumption during the contract } \\
\text { period and subsequent operation of whatever } \\
\text { facilities have been worked. }\end{array}$ \\
\hline \multirow{3}{*}{$\begin{array}{l}\text { Flora and } \\
\text { Fauna }\end{array}$} & $\begin{array}{l}\text { Protection of vegetation and } \\
\text { restoration of natural } \\
\text { vegetation and damaged } \\
\text { lands }\end{array}$ & {$[38,51-53]$} & $\begin{array}{l}\text { In the construction industry, establishing measures } \\
\text { to minimize the effect on natural vegetation is } \\
\text { important as well as protecting nonhazardous trees } \\
\text { and native plant communities and } \\
\text { planting/replacing vegetation in a way that extends } \\
\text { well beyond typical practices. }\end{array}$ \\
\hline & $\begin{array}{l}\text { Protection and control of } \\
\text { fauna species }\end{array}$ & {$[38,47,51,53,54]$} & $\begin{array}{l}\text { The extinction of threatened species needs to be } \\
\text { prevented. In the construction industry, the safe } \\
\text { passage of small fauna and amphibious or aquatic } \\
\text { species across the infrastructures need to be } \\
\text { ensured as well as during the construction. }\end{array}$ \\
\hline & $\begin{array}{l}\text { Erosion and sedimentation } \\
\text { plan }\end{array}$ & {$[26,38,50,55]$} & $\begin{array}{l}\text { Soil erosion decreasing agricultural productivity } \\
\text { and carbon sequestration capacities. Additionally, } \\
\text { reducing sedimentation during construction and in } \\
\text { adjacent areas can help protect water quality. }\end{array}$ \\
\hline
\end{tabular}

On the other hand, regarding the social dimension of sustainability, this can be understood as the processes for improving health, safety, and well-being conditions of any person affected directly or indirectly by development efforts [56]. Montalbán-Domingo et al. [14] established eight social categories to be considered in public procurement of the construction industry. These eight categories are: cultural heritage, employment, health and safety, local, professional ethics, public participation, training, and users' impact. Based on these categories, a literature review was performed to establish the subcategories associated with each of them. Table 2 gathers a brief description of each social subcategory.

Table 2. Social categories and subcategories.

\begin{tabular}{|c|c|c|c|}
\hline Category & Subcategory & Source & Justification and Explanation \\
\hline \multirow{2}{*}{$\begin{array}{l}\text { Cultural } \\
\text { Heritage }\end{array}$} & $\begin{array}{l}\text { Cultural heritage } \\
\text { appraisal and } \\
\text { management plan }\end{array}$ & {$[38,41,57,58]$} & $\begin{array}{l}\text { A historic environment management plan should be } \\
\text { defined if there are historic-environment aspects to the } \\
\text { site or its vicinity. }\end{array}$ \\
\hline & $\begin{array}{l}\text { Collaboration with } \\
\text { historical or cultural } \\
\text { preservationists }\end{array}$ & {$[38,57]$} & $\begin{array}{l}\text { Including appropriate historical environment } \\
\text { professionals (archaeologist, conservation architect, or } \\
\text { historic buildings specialist) on the project team to } \\
\text { manage and inspect the mitigation effort is } \\
\text { recommended in construction projects. }\end{array}$ \\
\hline \multirow{3}{*}{ Employment } & Employment creation & {$[59,60]$} & $\begin{array}{c}\text { The ratio of employee hires in an organization allows } \\
\text { showing the effort made by the organization to enhance } \\
\text { and revitalize the area where they operate. }\end{array}$ \\
\hline & Job stability & [60-62] & $\begin{array}{l}\text { Refers mainly to employee turnover. This allows } \\
\text { assessing the levels of uncertainty and dissatisfaction } \\
\text { among employees. }\end{array}$ \\
\hline & $\begin{array}{l}\text { Industry participation } \\
\text { plan }\end{array}$ & {$[57,63,64]$} & $\begin{array}{l}\text { In construction projects, the company needs to } \\
\text { determine the expected degree to which the project will } \\
\text { contribute to local firms' employment. }\end{array}$ \\
\hline
\end{tabular}


Table 2. Cont

\begin{tabular}{|c|c|c|c|}
\hline Category & Subcategory & Source & Justification and Explanation \\
\hline \multirow{4}{*}{$\begin{array}{l}\text { Health and } \\
\text { Safety }\end{array}$} & $\begin{array}{l}\text { Work health and safety } \\
\text { management officer }\end{array}$ & {$[63,65]$} & $\begin{array}{l}\text { The contractor should hire a competent person } \\
\text { authorized as a safety officer. }\end{array}$ \\
\hline & $\begin{array}{l}\text { Occupational health and } \\
\text { safety performance }\end{array}$ & {$[63,65-67]$} & $\begin{array}{l}\text { Occupational accidents lower employee productivity } \\
\text { and could be symptomatic of poor management quality } \\
\text { and lack of adequate internal management systems. }\end{array}$ \\
\hline & $\begin{array}{l}\text { Workplace health and } \\
\text { safety management plan }\end{array}$ & {$[38,60]$} & $\begin{array}{l}\text { The project team must define workplace health and } \\
\text { safety plans and programs according to the } \\
\text { characteristics and complexity of the project. }\end{array}$ \\
\hline & $\begin{array}{l}\text { Social benefits and social } \\
\text { security }\end{array}$ & {$[63,65,68]$} & $\begin{array}{l}\text { Occupational health and safety programs, services, and } \\
\text { systems prevent harm and protect workers from } \\
\text { work-related injuries and ill health. }\end{array}$ \\
\hline \multirow{3}{*}{$\begin{array}{c}\text { Local } \\
\text { Development }\end{array}$} & Local preference & [57] & $\begin{array}{l}\text { The inclusion of local criteria in public procurement can } \\
\text { protect local contractors and workers from foreign } \\
\text { companies. }\end{array}$ \\
\hline & $\begin{array}{l}\text { Local employment } \\
\text { through the use of local } \\
\text { products and services }\end{array}$ & {$[57,63]$} & $\begin{array}{l}\text { Encouraging the participation of local companies in } \\
\text { construction projects can have direct and indirect } \\
\text { benefits for the community. The employment of local } \\
\text { people or the use of local products and services can } \\
\text { reduce the distances traveled to and from work and } \\
\text { decrease the inconveniences over local communities. }\end{array}$ \\
\hline & Social value & {$[38,60,67,69,70]$} & $\begin{array}{l}\text { Social value is based on promoting social responsibility } \\
\text { on the contractors and subcontractors to commit to } \\
\text { acting in a socially responsible way, and boosting the } \\
\text { public commitments through training and raising } \\
\text { community awareness in relation to the sustainable } \\
\text { development. }\end{array}$ \\
\hline \multirow{8}{*}{$\begin{array}{l}\text { Professional } \\
\text { Ethics }\end{array}$} & $\begin{array}{l}\text { Nondiscrimination and } \\
\text { equal opportunities }\end{array}$ & {$[63,65,71]$} & $\begin{array}{l}\text { Organization that actively promotes diversity and } \\
\text { equality at work can directly generate significant } \\
\text { benefits for both the workers and organization. }\end{array}$ \\
\hline & $\begin{array}{l}\text { Fair wages and fair } \\
\text { income distributions }\end{array}$ & {$[63,65]$} & $\begin{array}{l}\text { It focuses on ensuring that workers are capable to } \\
\text { provide for their own needs and those of their families } \\
\text { and guarantees a minimum wage to contribute to } \\
\text { stability and prosperity in communities and attract more } \\
\text { skilled, productive, and loyal employees. }\end{array}$ \\
\hline & Child labor & {$[63,65]$} & $\begin{array}{l}\text { Child labor results in underskilled and unhealthy } \\
\text { workers for tomorrow and perpetuates poverty across } \\
\text { generations. }\end{array}$ \\
\hline & Forced labor & {$[63,65]$} & $\begin{array}{l}\text { It is expected of an organization to prevent and combat } \\
\text { all forms of forced or compulsory labor within its } \\
\text { activities, being essential to avoid contributing to or } \\
\text { becoming linked to the use of forced or compulsory labor } \\
\text { through its relationships with suppliers, clients, etc. }\end{array}$ \\
\hline & $\begin{array}{l}\text { Freedom of association } \\
\text { and collective bargaining }\end{array}$ & {$[63,65]$} & $\begin{array}{c}\text { Freedom of association and collective bargaining are } \\
\text { recognized as human rights by international conventions } \\
\text { and agreements. }\end{array}$ \\
\hline & Corruption & {$[63,65,72,73]$} & $\begin{array}{l}\text { Corruption and bribery imply serious moral and } \\
\text { political concerns, undermine good governance and } \\
\text { economic development, and distort international } \\
\text { competitive conditions. }\end{array}$ \\
\hline & $\begin{array}{l}\text { Respect of indigenous } \\
\text { rights }\end{array}$ & [63] & $\begin{array}{l}\text { The respect of indigenous rights must include their right } \\
\text { to lands, resources, cultural integrity, self-determination, } \\
\text { and self-government. }\end{array}$ \\
\hline & $\begin{array}{l}\text { Respect of intellectual } \\
\text { property rights }\end{array}$ & [63] & $\begin{array}{l}\text { Organizations must respect and safeguard the moral and } \\
\text { economic rights of the creators of intellectual property. }\end{array}$ \\
\hline $\begin{array}{c}\text { Public } \\
\text { Participation }\end{array}$ & $\begin{array}{l}\text { Community relations } \\
\text { program }\end{array}$ & {$[38,57,67,74-76]$} & $\begin{array}{l}\text { The views of stakeholders can be actively considered in } \\
\text { the construction stage of the project through an } \\
\text { appropriate community relations program during the } \\
\text { project. }\end{array}$ \\
\hline
\end{tabular}


Table 2. Cont.

\begin{tabular}{cccc}
\hline Category & \multicolumn{1}{c}{ Subcategory } & Source & \multicolumn{1}{c}{ Justification and Explanation } \\
\hline Training & Technical training & {$[38,40,65]$} & $\begin{array}{c}\text { Training of employees reflects in their skills and } \\
\text { capabilities, improving their performance and } \\
\text { productivity. }\end{array}$ \\
\cline { 2 - 4 } & Sustainability training & {$[60,65,73,77-79]$} & $\begin{array}{c}\text { To boost the organization's capacity to implement its } \\
\text { human rights policies and procedures, specialized } \\
\text { training has to be implemented in organizations to } \\
\text { identify, prevent, and mitigate their negative human } \\
\text { rights impacts. }\end{array}$ \\
\hline Users' Impact & Effects on neighbors & {$[38,57,67]$} & $\begin{array}{c}\text { A traffic management plan to limit the impact on users } \\
\text { during the construction period is demanded, as well as } \\
\text { the definition of control measures to put in place to } \\
\text { minimize noise, dust, and pollution during the } \\
\text { construction works. }\end{array}$ \\
\hline
\end{tabular}

\section{Research Method}

\subsection{Overall Approach}

This research characterized the social and environmental deficiencies that exist in the EU countries. Cook et al. [26] proposed the use of national indicators to evaluate and compare the sustainable performance of each country. Based on this, the methodology presented used national indicators to characterize these deficiencies. For that purpose, firstly, the databases that should be considered to extract the sustainability indicators of each country were selected. Indicators related to the proposed environmental and social categories were identified in each database. Subsequently, these indicators were evaluated and a statistical analysis was carried out in order to analyze the relationship between the selected indicators. Finally, the Promethee tool was applied to characterize the sustainable performance of the European countries and the results were assessed through a cluster analysis.

Out of the eight social categories, employment, health and safety, professional ethics, and training are addressed in this work. The categories of cultural heritage, local development, public participation, and users' impact depend on the specific context of each project and, therefore, could not be assessed through national indicators. On the other hand, the subcategories of child labor, forced labor, freedom of association and collective bargaining, corruption, respect of indigenous rights, and respect of intellectual property rights are fundamental human rights to be duly fulfilled by each member state.

\subsection{Selection of National Indicators}

Identifying the social weaknesses in a country is largely determined by the appropriateness of the national indicators used [19]. In this regard, a large number of organizations have contributed significantly to the development of sustainable development indicators at the national level [21]. Organizations such as Eurostat [80], the Organization for Economic Co-operation and Development (OECD) [81], the Sustainable Governance Indicators (SGI) [82], the International Labor Organization (ILO) [83], or the United Nations Conference on Sustainable Development (UNCSD) [84], among others, have a wide sample of national indicators in different fields. Therefore, in order to guarantee the appropriateness of the national indicators to use in this research, data sources possessing a quality assurance framework, such as those belonging to the Eurostat database [26], are preferred whenever possible.

A top-down approach was defined to evaluate, screen, and filter national indicators [85]. A 'theoretical' assessment was undertaken to evaluate the national indicators according to a set of quality criteria. Different quality criteria exist in the literature review to assess national indicators. Cook et al. [26] proposed the following quality criteria to select indicators to measure countries' environmental sustainability performance: policy relevance, utility, soundness, interpretability, and data availability and quality. Nardo et al. [86] highlighted that national indicators should 
be selected based on their analytical soundness, measurability, country coverage, and relevance to the phenomenon being measured. The International Monetary Fund uses the following criteria: assurance of integrity, methodological soundness, accuracy and reliability, serviceability, and accessibility [87]. Therefore, six quality criteria were defined to assess the national indicators: (1) relevance, to select the indicators related to some environmental or social category; (2) utility, to judge if the indicators were easily understandable; (3) measurable, to assess if the indicator was defined at the national scale; (4) countries coverage, to select the indicators which were available for all the EU countries; (5) time coverage, to screen indicators with data available for some of the years 2014, 2015, and 2016; and (6) soundness, to filter only those indicators with metadata available.

The databases of Eurostat [80], ILO [83], OECD [81], SGI [82], UNCSD [84], and the World Bank [88] were analyzed, and national indicators were selected only in case these satisfied the criteria relevance and utility. In this first filter, 186 environmental indicators and 153 social indicators were collected. These were subjected to a second screening based on the criteria measurable, time coverage, and soundness. This analysis resulted in 54 environmental indicators and 68 social indicators. After rejecting redundant indicators, 42 national indicators were selected (18 environmental and 24 social).

\subsection{Discrimination Analysis}

The coefficient of variation (CV) of each indicator was used to select only those indicators whose information is relevant to highlight the differences between countries in the sample [19]. This method has been widely used to simplify system analyses and obtain optimal subsets of national indicators [89]. When an indicator has similar values for all the countries, this represents that the discrimination of this indicator is too weak to recognize the differences among them [19]. CV can be calculated as the ratio between the standard deviation and the average value of each indicator (Equation (1)).

$$
C V_{i}=\frac{\sqrt{\frac{1}{n-1} \sum\left(X_{i}-\bar{X}\right)^{2}}}{\bar{X}}
$$

where $\bar{X}$ is the average value $\left(\frac{1}{n} \sum_{i=1}^{n} X_{i}\right)$. The $C V$ was calculated using SPSS 23.0 software. Low values of $\mathrm{CV}$ indicate that the indicator is too weak to discriminate the performance of the countries and the higher the $\mathrm{CV}$, the more heterogeneous the sample is considered. Therefore, if it is lower than an established value, the indicator is removed from the analysis because it does not show diversified information. In this work, 0.10 was used as an acceptable reference level [90].

\subsection{Correlation Analysis}

To assess the suitability of the dataset, a correlation analysis was performed. A correlation analysis allows for identifying those indicators that provide identical information. Through this method, multicollinearity can be detected, and redundant indicators can be excluded [87]. Multicollinearity is identified through the correlation matrix. The multicollinearity corresponds to those indicators most highly correlated (coefficient correlation above 0.80 ).

According to Field [91], three types of correlation coefficients can be calculated to define the correlation matrix: (1) Pearson's correlation coefficient, which requires a normally distributed sample to assess the significance of the correlation; (2) Spearman's correlation coefficient, which is a nonparametric statistic and can be used when the data do not present a normal distribution; and, (3) Kendall's tau, which is another nonparametric correlation. The latter is recommended rather than Spearman's coefficient when the dataset is small, offering, in small samples, a better estimate of the correlation. These tests assume as null hypothesis that the correlation coefficient between variables is not significantly different from zero, being satisfied with this condition when the p-value is less than 0.5 [92]. Additionally, these correlation coefficients ( $\mathrm{r}$ ) represent the standardized covariance. The coefficients go from -1 to +1 . A coefficient of +1 indicates that the two variables are perfectly positively correlated; a coefficient of -1 indicates a perfect negative relationship and a coefficient of zero indicates no linear relationship. 
To measure the size of an effect, values of \pm 0.1 represent a small effect, \pm 0.3 a medium effect, and \pm 0.5 a large effect [91].

Thus, to select the correlation analysis to be performed, the normality of the sample was analyzed. Taking into account that the sample includes 28 countries, the Shapiro-Wilk test of normality was applied because the sample size was small (less than 50) [92]. This test compares the scores in the sample to a normally distributed set of scores with the same mean and standard deviation. If the test is nonsignificant $(p>0.05)$, the distribution of the sample is not significantly different from a normal distribution. However, if the test is significant $(p<0.05)$, the distribution in question is significantly different from a normal distribution [91]. Therefore, after analyzing the normality of the sample, the appropriate method of the correlation analysis was used to delete the highly correlated indicators (coefficient correlation above 0.80 ), resulting in the final list of national indicators.

\subsection{Promethee}

The Promethee method was developed by Jean-Pierre Brans in 1980s [93]. This method can provide a ranking of countries, from the best to the worst, based on their performances in a finite set of indicators [94]. This method is based on a pairwise comparison of countries along each indicator. Countries are evaluated according to different indicators, which have to be maximized or minimized. The Promethee includes both the Promethee I and the Promethee II. Promethee I performs a partial ranking in order to calculate the extent to which the performance of a country is better than the others (positive outranking flow- $\Phi^{+}(\mathrm{a})$ ), and the extent to which it is worse than the other countries (negative outranking flow $\left.\Phi^{-}(\mathrm{a})\right)$ [95]. Promethee II calculates a net outranking flow $(\Phi(\mathrm{a}))$ for each country, determining its ranking based on Promethee I partial positive $\left(\Phi^{+}(\mathrm{a})\right)$ and negative $\left(\Phi^{-}(\mathrm{a})\right)$ flow rankings (Equation (2)) [95]:

$$
(a)=\Phi^{+}(a)-\Phi^{-}(a)
$$

The positive $\left(\Phi^{+}(\mathrm{a})\right)$ and negative $\left(\Phi^{-}(\mathrm{a})\right)$ flow rankings are evaluated based on the positive and negative differences between the evaluations of the alternatives on each indicator. For each indicator, a preference function must be computed to translate the difference between the evaluations obtained by two countries into a preference degree ranging from zero to one [96]. The preference function is the V-shaped function with the strict preference threshold (p); this is the maximum value of each indicator, if the indicators need to be maximized, while, in the case of indicators to be minimized, the value of this threshold will be the maximum as well, but with a negative sign [97]. In addition, this method requires the definition of weights and the selection of preference functions that convert the difference between alternatives into a ranging [22]. As defining weights in sustainability assessment is a highly subjective task [63], in this research, the weights were set to 1 for all the indicators, considering that every indicator had the same level of importance. Behzadian et al. [96] presented a detailed description of Promethee II. In this study, the analyzed sample was based on the 28 EU countries: Austria, Belgium, Bulgaria, Croatia, Cyprus, Czech Republic, Denmark, Estonia, Finland, France, Germany, Greece, Hungary, Ireland, Italy, Latvia, Lithuania, Luxembourg, Malta, the Netherlands, Poland, Portugal, Romania, Slovakia, Slovenia, Spain, Sweden, and the United Kingdom.

\subsection{Cluster Analysis}

Finally, a cluster analysis was applied to analyze the results of Promethee. This method is the most appropriate hierarchical conglomerate analysis for small samples [98] and allows researchers to group the countries according to their performances in each criteria. The grouping method selected was the Ward method [99]. This method minimizes intergroup variance, while uniformity within the groups is maximized [91]. As the method is highly sensitive to outliers [98], the squared Euclidean distance was considered to assess the distance measures between observation units. 


\section{Results}

\subsection{Selected Indicators}

A set of 41 indicators was obtained (see Table 3), of which the coefficient of variation (CV) was in all cases greater than 0.10 . This last set was with the values recorded from 2014 to 2017, and an average was calculated between these four years, since not all countries presented data for all years.

Table 3. Environmental and social national indicators.

\begin{tabular}{|c|c|c|c|c|}
\hline Categories & National Indicators & Unit & Source & $\mathrm{CV}$ \\
\hline \multirow{3}{*}{ E1: Energy } & $\begin{array}{l}\text { Share of renewable energy in } \\
\text { gross final energy consumption }\end{array}$ & $\%$ & Eurostat database & 0.60 \\
\hline & Final energy consumption & $\begin{array}{l}\text { Millions of tons of oil } \\
\text { equivalent }\end{array}$ & Eurostat database & 0.49 \\
\hline & Fossil fuel energy consumption & $\%$ & Eurostat database & 0.27 \\
\hline \multirow{4}{*}{ E2: Emissions } & $\mathrm{CO}_{2}$ emissions & Metric tons per capita & Eurostat database & 0.47 \\
\hline & $\begin{array}{c}\mathrm{CO}_{2} \text { emissions from } \\
\text { manufacturing industries and } \\
\text { construction }\end{array}$ & $\begin{array}{l}\% \text { of total fuel } \\
\text { combustion }\end{array}$ & Eurostat database & 0.36 \\
\hline & $\begin{array}{l}\text { PM2.5 air pollution, population } \\
\text { exposed to levels exceeding WHO } \\
* \text { guideline value }\end{array}$ & $\%$ of total & Eurostat database & 0.45 \\
\hline & Greenhouse gas emissions & Metric tons per capita & Eurostat database & 0.36 \\
\hline \multirow[t]{2}{*}{ E3: Waste } & $\begin{array}{l}\text { Generation of waste excluding } \\
\text { major mineral wastes by } \\
\text { hazardousness }\end{array}$ & kg per capita & Eurostat database & 0.80 \\
\hline & Waste in the construction sector & $\mathrm{kg}$ per capita & Eurostat database & 1.43 \\
\hline \multirow[b]{2}{*}{ E4: Water } & Annual freshwater withdrawals & $\%$ of internal resources & World Bank ** & 1.16 \\
\hline & $\begin{array}{c}\text { Percentage of anthropogenic } \\
\text { wastewater that receives } \\
\text { treatment }\end{array}$ & $\%$ & World Bank ** & 0.80 \\
\hline \multirow{6}{*}{$\begin{array}{l}\text { E5: Flora and } \\
\text { Fauna }\end{array}$} & $\begin{array}{l}\text { Adjusted savings: natural } \\
\text { resources depletion }\end{array}$ & $\%$ of GNI & World Bank ** & 1.32 \\
\hline & $\begin{array}{l}\text { Adjusted savings: net forest } \\
\text { depletion }\end{array}$ & $\%$ of GNI & World Bank ** & 4.27 \\
\hline & Bird species, threatened & Number & World Bank ** & 0.33 \\
\hline & Fish species, threatened & Number & World Bank ** & 0.91 \\
\hline & Mammal species, threatened & Number & World Bank ** & 0.78 \\
\hline & Plant species, threatened & Number & World Bank ** & 1.70 \\
\hline \multirow{10}{*}{ S1: Employment } & Temporary employment & $\%$ & Eurostat database & 0.57 \\
\hline & $\begin{array}{l}\text { Unemployment with advanced } \\
\text { education }\end{array}$ & $\begin{array}{l}\% \text { of total labor force } \\
\text { with advanced } \\
\text { education }\end{array}$ & World Bank *** & 0.72 \\
\hline & $\begin{array}{l}\text { Unemployment with basic } \\
\text { education }\end{array}$ & $\begin{array}{l}\% \text { of total labor force } \\
\text { with basic education }\end{array}$ & World Bank *** & 0.44 \\
\hline & $\begin{array}{l}\text { Unemployment with intermediate } \\
\text { education }\end{array}$ & $\begin{array}{l}\% \text { of total labor force } \\
\text { with intermediate } \\
\text { education }\end{array}$ & World Bank *** & 0.62 \\
\hline & Unemployment, female & $\%$ & World Bank *** & 0.60 \\
\hline & Unemployment, total & $\%$ & World Bank *** & 0.51 \\
\hline & Youth unemployment rate & $\begin{array}{l}\% \text { of labor force ages } \\
15-24\end{array}$ & World Bank *** & 0.50 \\
\hline & Job tenure & $\%$ of labor force & World Bank *** & 0.24 \\
\hline & Long-term unemployment rate & $\%$ of unemployed & Eurostat database & 0.80 \\
\hline & $\begin{array}{l}\text { Unemployment rate of } \\
\text { foreign-born }\end{array}$ & $\%$ of unemployed & Eurostat database & 0.51 \\
\hline
\end{tabular}


Table 3. Cont.

\begin{tabular}{|c|c|c|c|c|}
\hline Categories & National Indicators & Unit & Source & $\mathrm{CV}$ \\
\hline \multirow{4}{*}{$\begin{array}{l}\text { S2: Health and } \\
\text { Safety }\end{array}$} & Death rate due to chronic disease & $\begin{array}{l}\text { Number per } 100,000 \\
\text { persons aged less than } \\
65\end{array}$ & Eurostat database & 0.38 \\
\hline & Fatal accidents at work & $\begin{array}{l}\text { Number of fatal } \\
\text { accidents per } 100,000 \\
\text { workers }\end{array}$ & Eurostat database & 0.54 \\
\hline & Nonfatal accidents at work & $\begin{array}{l}\text { Number of nonfatal } \\
\text { accidents per } 100,000 \\
\text { workers }\end{array}$ & Eurostat database & 0.90 \\
\hline & Public health expenditure & $\%$ of GDP & Eurostat database & 0.22 \\
\hline \multirow{8}{*}{$\begin{array}{l}\text { S3: Professional } \\
\text { Ethics }\end{array}$} & $\begin{array}{l}\text { Employed women being in } \\
\text { managerial positions }\end{array}$ & $\begin{array}{l}\% \text { employed persons in } \\
\text { managerial positions }\end{array}$ & Eurostat database & 0.18 \\
\hline & $\begin{array}{l}\text { Ratio of female to male labor force } \\
\text { participation rate }\end{array}$ & $\%$ & World Bank ${ }^{* * *}$ & 0.12 \\
\hline & Ratio of female to male salary & $\%$ & Eurostat database & 0.13 \\
\hline & Human development index & Scale of 0 to 100 & Eurostat database & 0.11 \\
\hline & $\begin{array}{l}\text { Employed persons at risk of } \\
\text { poverty rate }\end{array}$ & $\%$ of labor force & Eurostat database & 0.41 \\
\hline & $\begin{array}{l}\text { Unemployment rate of disabled } \\
\text { people }\end{array}$ & $\%$ of unemployed & World Bank *** & 0.40 \\
\hline & $\begin{array}{l}\text { Unemployment rate of } \\
\text { foreign-born }\end{array}$ & $\%$ of unemployed & Eurostat database & 0.51 \\
\hline & Corruption Perception Index & Scale of 0 to 100 & Eurostat database & 0.20 \\
\hline \multirow{3}{*}{ S4: Training } & $\begin{array}{l}\text { Employed persons participating } \\
\text { in job-related nonformal } \\
\text { education and training in the past } \\
12 \text { months }\end{array}$ & $\%$ of labor force & Eurostat database & 0.33 \\
\hline & Patent applications & $\begin{array}{l}\text { Number per million } \\
\text { inhabitants }\end{array}$ & Eurostat database & 1.17 \\
\hline & $\begin{array}{l}\text { Research and development } \\
\text { expenditure }\end{array}$ & $\%$ of GDP & Eurostat database & 0.55 \\
\hline
\end{tabular}

${ }^{*}$ WHO: World Health Organization; ** World Development Indicators database; ***; ILOSTAT database.

To determine the correlation analysis, the normality of the sample was analyzed. The results of the Shapiro-Wilk normality tests showed that only 13 indicators were normally distributed ( $p$-value $>0.05$ ). Therefore, the correlation matrix was calculated through Kendall's tau test. The correlation analysis was carried out using IBM SPSS Statistics 23.0. Table 4 shows the correlated indicators characterized by multicollinearity (Kendall's correlations $>0.8$ ). As it can be observed, the indicator "unemployment total" was highly correlated with the indicators: "long-term unemployment rate" (0.801), "unemployment female" (0.887), "youth unemployment rate" (0.820), "unemployment rate by foreign-born" (0.802), "unemployment with advanced education" (0.836), "unemployment with intermediate education" (0.819), and "unemployment with basic education" (0.855). Similarly, the indicator "patent applications" was highly correlated with "research and development expenditure" (0.814). Consequently, the indicators "unemployment total" and "research and development expenditure" were considered, and the rest of the indicators characterized by multicollinearity were rejected.

\subsection{Promethee Results}

As a result of using Promethee, a ranking of countries for each category was obtained. Table 5 presents the net preference flows of each category for the 28 EU Countries. The best and the worst performances for each category are highlighted in bold. Regarding the environmental categories, Luxemburg was the country with the worst performances in energy (E1: -0.41$)$, emissions (E2: -0.31 , and waste (E3: -0.45); however, this country had the best performances in water (E4: 0.24) and flora and fauna (E5: 0.24). With regard to the social categories, the countries with the best performances were: 
Romania in employment (S1: 0.31), Sweden in health and safety (S2: 0.25), and Finland in professional ethics and training. Spain showed the worst performances in the categories of employment (S1: -0.40$)$ and professional ethics (S3: -0.13). Greece showed the worst performance in training (S4: -0.41).

Table 4. Main results of correlation analysis.

\begin{tabular}{|c|c|c|c|}
\hline Correlated Indicators & Correlation Coefficient & Sig. (2-Tailed) & $\mathbf{N}$ \\
\hline Long-term unemployment rate-Unemployment, total & 0.801 & 0.000 & 28 \\
\hline Unemployment, female-Unemployment, total & 0.887 & 0.000 & 28 \\
\hline Youth unemployment rate-Unemployment, total & 0.820 & 0.000 & 28 \\
\hline $\begin{array}{c}\text { Unemployment rate by foreign-born-Unemployment, } \\
\text { total }\end{array}$ & 0.802 & 0.000 & 28 \\
\hline $\begin{array}{l}\text { Unemployment with advanced } \\
\text { education-Unemployment, total }\end{array}$ & 0.836 & 0.000 & 28 \\
\hline $\begin{array}{l}\text { Unemployment with intermediate } \\
\text { education-Unemployment, total }\end{array}$ & 0.819 & 0.000 & 28 \\
\hline $\begin{array}{l}\text { Unemployment with basic } \\
\text { education-Unemployment, total }\end{array}$ & 0.855 & 0.001 & 28 \\
\hline $\begin{array}{c}\text { Patent applications-Research and development } \\
\text { expenditure }\end{array}$ & 0.814 & 0.000 & 28 \\
\hline
\end{tabular}

Table 5. Net preference flow of each category.

\begin{tabular}{|c|c|c|c|c|c|c|c|c|c|}
\hline Country & E1 & E2 & E3 & E4 & E5 & S1 & S2 & S3 & S4 \\
\hline Austria & 0.02 & -0.10 & -0.14 & 0.05 & 0.08 & 0.07 & 0.07 & 0.07 & 0.25 \\
\hline Belgium & -0.16 & -0.17 & -0.07 & -0.11 & 0.15 & 0.10 & 0.03 & 0.10 & 0.20 \\
\hline Bulgaria & 0.06 & 0.02 & 0.04 & -0.14 & -0.19 & 0.17 & -0.10 & -0.06 & -0.35 \\
\hline Croatia & 0.12 & 0.01 & 0.14 & -0.08 & -0.15 & -0.18 & 0.01 & -0.05 & -0.24 \\
\hline Cyprus & -0.04 & -0.04 & 0.10 & -0.35 & 0.08 & -0.22 & -0.01 & -0.02 & -0.32 \\
\hline Czech Republic & -0.06 & -0.14 & 0.08 & 0.06 & 0.14 & 0.14 & 0.05 & -0.03 & 0.19 \\
\hline Denmark & 0.07 & 0.06 & 0.00 & 0.19 & 0.02 & -0.07 & 0.08 & 0.10 & 0.22 \\
\hline Estonia & 0.15 & 0.07 & -0.36 & 0.07 & 0.15 & 0.11 & 0.00 & -0.06 & 0.13 \\
\hline Finland & -0.02 & 0.12 & -0.14 & 0.17 & 0.11 & -0.10 & 0.02 & 0.13 & 0.43 \\
\hline France & 0.02 & 0.00 & -0.06 & 0.11 & -0.10 & -0.05 & -0.11 & 0.03 & 0.13 \\
\hline Germany & -0.09 & -0.10 & -0.04 & 0.23 & 0.03 & 0.07 & 0.06 & 0.01 & 0.23 \\
\hline Greece & 0.01 & 0.00 & 0.07 & 0.10 & -0.22 & -0.15 & 0.05 & -0.12 & -0.41 \\
\hline Hungary & 0.03 & 0.00 & 0.10 & -0.40 & 0.04 & 0.07 & -0.12 & -0.07 & -0.16 \\
\hline Ireland & -0.08 & 0.10 & 0.07 & 0.12 & 0.07 & 0.06 & 0.07 & 0.03 & 0.12 \\
\hline Italy & 0.01 & 0.02 & 0.05 & 0.06 & -0.15 & -0.02 & 0.05 & -0.05 & -0.12 \\
\hline Latvia & 0.18 & 0.04 & 0.12 & 0.13 & 0.15 & 0.09 & -0.02 & -0.01 & -0.18 \\
\hline Lithuania & 0.08 & 0.03 & 0.12 & -0.02 & 0.15 & 0.08 & -0.16 & -0.07 & -0.14 \\
\hline Luxembourg & -0.41 & -0.31 & -0.45 & 0.24 & 0.24 & 0.09 & -0.03 & 0.02 & 0.06 \\
\hline Malta & -0.05 & 0.13 & -0.01 & -0.44 & 0.16 & 0.16 & -0.06 & 0.02 & -0.12 \\
\hline Netherlands & -0.19 & -0.15 & -0.22 & -0.24 & 0.02 & -0.06 & 0.23 & 0.07 & 0.19 \\
\hline Poland & -0.04 & -0.05 & 0.06 & -0.04 & -0.14 & -0.11 & 0.04 & 0.02 & -0.13 \\
\hline Portugal & 0.10 & 0.22 & 0.11 & -0.04 & -0.21 & -0.17 & -0.30 & -0.03 & -0.15 \\
\hline Romania & 0.12 & -0.02 & 0.12 & -0.25 & -0.17 & 0.31 & -0.16 & -0.09 & -0.36 \\
\hline Slovak Republic & 0.00 & -0.03 & 0.08 & 0.03 & 0.05 & 0.03 & 0.04 & -0.06 & -0.03 \\
\hline Slovenia & 0.03 & -0.15 & 0.10 & 0.03 & 0.08 & -0.03 & -0.05 & 0.07 & 0.20 \\
\hline Spain & 0.03 & 0.17 & 0.09 & 0.07 & -0.42 & -0.40 & -0.11 & -0.13 & -0.11 \\
\hline Sweden & 0.17 & 0.24 & 0.03 & 0.23 & 0.11 & -0.12 & 0.25 & 0.12 & -0.02 \\
\hline UK & -0.06 & 0.03 & 0.01 & 0.24 & -0.08 & 0.12 & 0.19 & 0.06 & 0.13 \\
\hline
\end{tabular}

Note: E1: energy, E2: emissions, E3: waste, E4: water, E5: flora and fauna, S1: employment, S2: health and safety, S3: professional ethics, S4: training. 
Figure 1 shows the performance of each category for each country according to their positions in the rankings. For example, Austria showed the worst performances, first, in the categories emissions and waste and, second, in water. However, this country was in the best position regarding training, health and safety, and professional ethics. Ireland presented a good performance for most of the categories except for energy. Denmark and Slovak's republic did not occupy positions over 21 for any category.

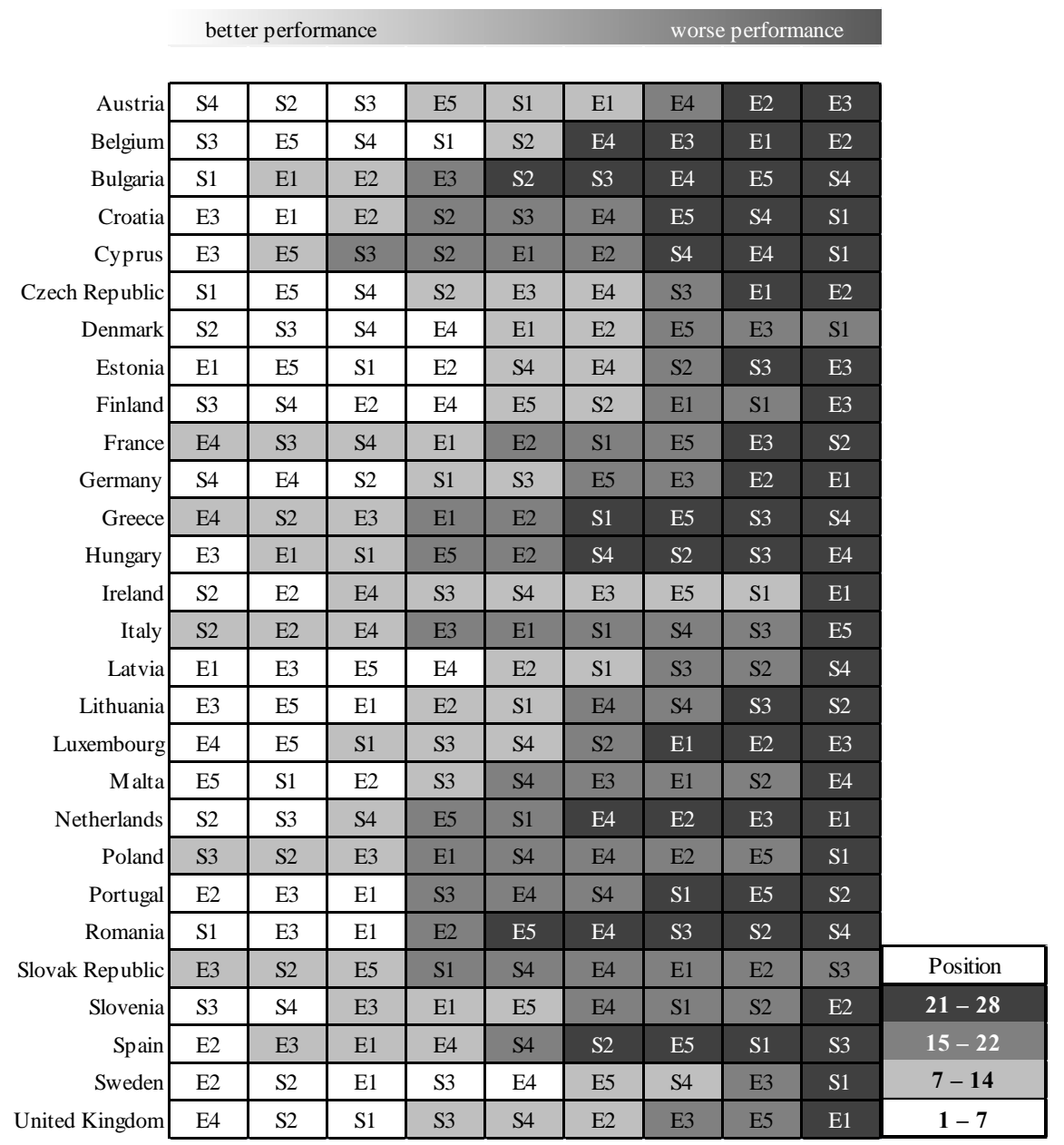

Figure 1. Performance of the EU countries. Note: E1: Energy; E2: Emissions; E3: Waste; E4: Water; E5: Flora and Fauna; S1: Employment; S2: Health and Safety; S3: Professional Ethics; S4: Training.

Finally, in order to understand the sustainable behavior of the EU countries, a cluster analysis was applied. Two groups of countries were identified. Figure 2 shows the results of the hierarchical agglomeration for the observed EU countries. On the basis of the results of the cluster analysis, it can be stated that two groups can be identified in terms of sustainable development. The first cluster consists of Germany, Austria, Czech Republic, Belgium, Netherlands, Luxembourg, Ireland, United Kingdom, Denmark, Sweden, and Finland. The second cluster is made up of Slovak Republic, Italy, Poland, Cyprus, Slovenia, France, Spain, Portugal, Croatia, Greece, Estonia, Malta, Hungary, Lithuania, Bulgaria, Romania, and Latvia. 


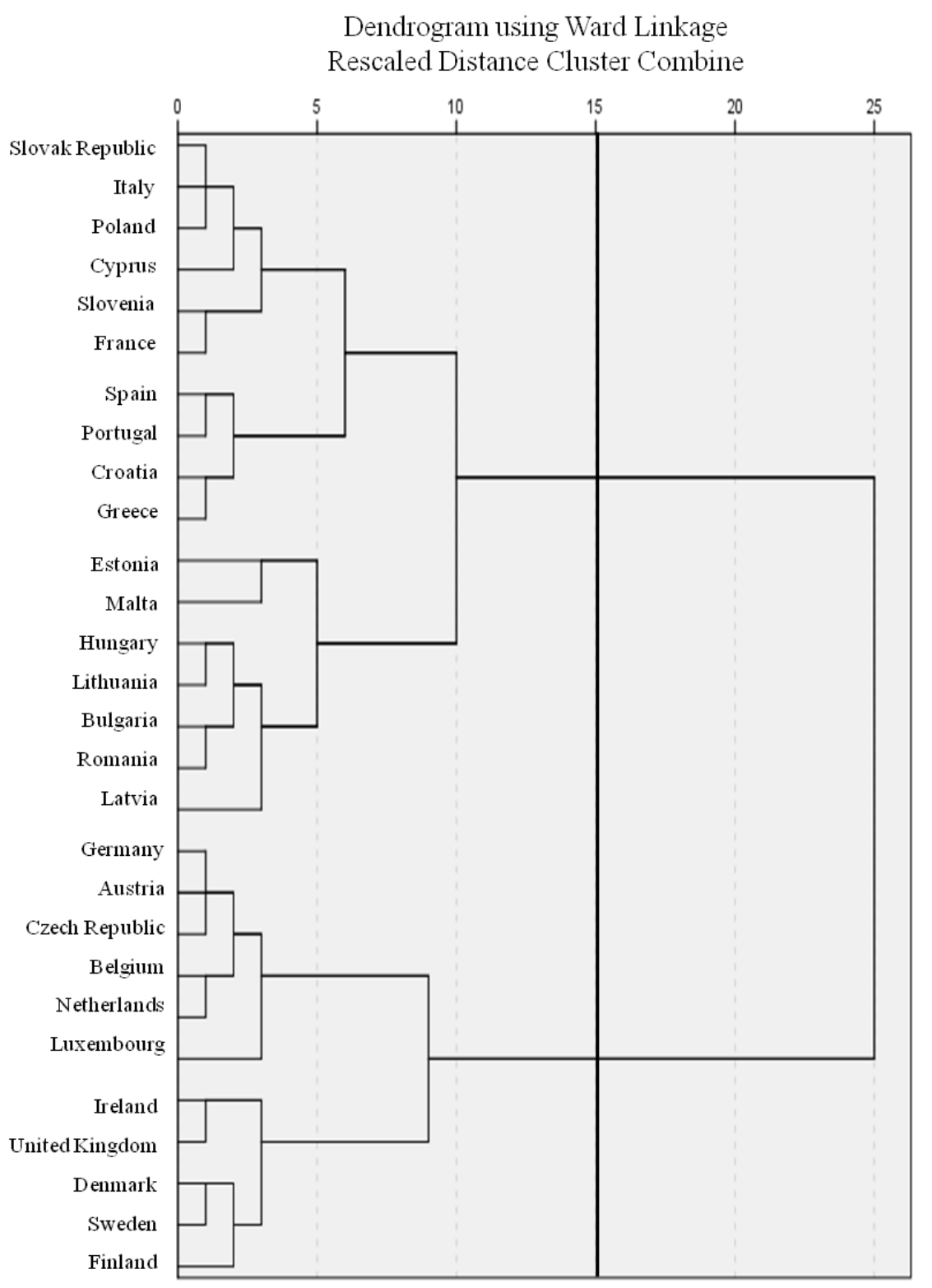

Figure 2. Dendrogram of cluster analysis.

\section{Discussion}

Most of the EU countries have implemented policies to improve their sustainable performance [100]. In this regard, two groups have been identified through the cluster analysis. The first one consists of the most economically developed EU countries (north-west axis): Germany, Austria, Czech Republic, Belgium, Netherlands, Luxembourg, Ireland, United Kingdom, Denmark, Sweden, and Finland. These countries have fostered strong strategies to improve their sustainability performance for years $[22,95]$ and share a good performance in social sustainability, with a high level of human, and inclusive development [22]. However, as Szopik-Depczyńska et al. [20] stated, a greater volume of economic activities leads to worse results in the environmental indicators with respect to countries with less economic activities. For that reason, this group of countries needs to continue working on the improvement of their environmental performance. On the other hand, countries in the second cluster are the least successful in achieving their sustainable development goals. This set corresponds with the less developed economies in Europe (south-east axis). These countries are: Slovak Republic, Italy, Poland, Cyprus, Slovenia, France, Spain, Portugal, Croatia, Greece, Estonia, Malta, Hungary, Lithuania, Bulgaria, Romania, and Latvia. These countries share the need to make an effort mainly 
in social sustainability, with it being necessary to improve their performances in aspects such as full employment, professional ethics, and training, without ignoring their performance in the environmental aspects [22,95]. In order to achieve a deeper understanding, the main results for each environmental and social category are analyzed in-depth in the following sections.

\subsection{Energy}

Latvia, Sweden, Estonia, Romania, and Croatia were in the top five places; however, Germany, Belgium, Netherlands and Luxemburg showed the worst energy performance. Some authors [20,22] have indicated that more economically developed countries will score poorer more often than less developed countries [101], as a greater volume of economic activities leads to more energy consumption [102]. Although Sweden was one of the countries with the highest energy consumption, this country was by far the best performer in renewable energy, since the $54 \%$ of its energy came from renewable energy, followed by Latvia, Austria, and Denmark. However, Romania has a good position in the ranking because this country presented the lowest energy consumption. Regarding Latvia and Estonia, their energy consumptions were among the average values of EU countries; however, these countries had high percentages of renewable energy (37.8\% Latvia and $27.9 \%$ Estonia).

Congestion can greatly influence vehicle fuel consumption due to queues and associated slowdown, both in the construction and in the maintenance phase of high traffic roads.

\subsection{Emissions}

For this criterion, Sweden, Portugal and Spain showed the best performances. Sweden was the country with the best values in population exposed to levels that exceed the World Health Organization reference value and emissions of greenhouse gases. Portugal and Spain obtained the second and third position thanks to their performances in $\mathrm{CO}_{2}$ emissions and PM2.5 air pollution. On the other hand, Luxemburg, Belgium, and Netherlands showed the highest values in emissions generation, results which were in line with the energy results [22]. These results were expected as, according to the European Environmental Agency [103], the largest proportion of emissions come from energy production and consumption.

\subsection{Waste}

Croatia, Latvia, Romania, and Lithuania were the countries with the lowest values in waste generation. In this regard, it is important to highlight that waste generation directly depends on the population, the economic development of the country, and the main activities carried out [22]. Additionally, the indicator "waste generation excluding the main dangerous mineral waste" excludes the main mineral wastes such as dredging offal and contaminated soils. Large quantities of mineral waste are produced in some countries such as Romania [103], allowing the country to be among the first places.

\subsection{Water}

Luxembourg, the United Kingdom, and Sweden were in the top three positions as they presented the best values of "annual freshwater withdrawals" and "percentage of anthropogenic wastewater that receives treatment". According to Kristensen et al. [104], the extraction of fresh water depends in part on several socioeconomic factors, mainly population, physiography, and climatic characteristics. Additionally, Antanasijević et al. [22] highlighted that countries such as Cyprus, Estonia, or the Netherlands have shown a negative trend in the overexploitation of natural resources. Although, in general, the EU countries perform well in terms of the extraction of fresh water in comparison with the rest of the world [105], there is a lack of adequate sanitation systems in countries such as Malta, Hungary, Cyprus, and Romania, which penalizes their water performance. 


\subsection{Flora and Fauna}

As with the water category, Luxembourg had the best performance under the flora and fauna criterion, followed by Malta and Latvia. On the contrary, Spain, Greece, Portugal, and Bulgaria were in the last places. Despite the fact that Spain is the country with the greatest biological wealth in Europe thanks to its geographical location and climatic factors, it suffers a strong loss of biodiversity and it is the country with the highest number of threatened species. Aspects such as the pressure from disrespectful tourism with nature, the use of pesticides, and pollution contribute to the risk of the disappearance of some species [102].

\subsection{Employment}

Romania, Bulgaria, and Malta had the best situation regarding employment indicators. This was mainly because of the indicators "temporary employment" and "job tenure", where these countries had the best performances. The combination of high shares of temporary contracts and low transition rates towards permanent contracts is symptomatic of the EU labor market duality [106]. In this regard, Spain, Cyprus, Croatia, Portugal, and Greece were the bottom five countries in employment performance. Currently, their economic systems do not produce enough employment opportunities and these countries need to improve their performances in youth unemployment and foster the integration of the long-term unemployed in order to avoid negative consequences for social cohesion and potential growth [106].

\subsection{Health and Safety}

The first places were occupied by Sweden, Netherlands, the United Kingdom, Denmark, Austria, and Germany. On the other hand, the countries with the worst performance in health and safety were Portugal, Romania, Lithuania, Hungary, and Spain. Although the majority countries have made long-term progress regarding public health [22], countries such as Romania, Hungary, and Lithuania still show deficiencies in the death rate due to chronic diseases and high ratios in fatal and nonfatal accidents. Additionally, measures should be taken to improve working conditions of health workers in the construction industry of countries such as Romania, Portugal, Spain, and Lithuania [106], which is characterized by competitive processes with high participation of subcontractors and extended supply chains that along with ever-changing work environment and harsh working conditions, make it dangerous $[77,107]$.

\subsection{Professional Ethics}

The most economically developed EU countries, such as Finland, Sweden, Belgium, Denmark, Netherlands, Austria, and the United Kingdom showed the best performance in professional ethics. In countries such as Lithuania, Spain, Hungary, and Slovakia, significant barriers exist for persons with disabilities in accessing the labor market growth [106]. The total number of people at risk of poverty or social exclusion has improved in comparison with the level around the start of the economic crisis [102]. However, countries such as Romania, Greece, Spain, Italy, and Poland showed percentages over the $11 \%$ of the population. Gender equality needs to be boosted in countries such as Malta, Italy, Romania, and Hungary in order to improve the ratio of female to male labor force participation. In addition, wage differences must be overcome in Estonia, Czech Republic, Germany, Austria, and the United Kingdom to achieve the gender equality. Finally, the most economically developed countries showed the best performance regarding the human development and the corruption perception.

\subsection{Training}

Countries such as Finland, Austria, Germany, Denmark, and Belgium showed the best performances in training criteria. On the opposite side, the worst positioned countries were Greece, Romania, Bulgaria, Cyprus, and Croatia. Training is essential to increase the knowledge, skills, and capacity 
of workers [38,40]. Members states, such as Greece, Bulgaria, Romania, Cyprus, Hungary, Portugal, and Croatia need to adapt their skills development systems to improve labor market growth [106]. On the other hand, one of the headline targets of Europe is to achieve research and development intensity [108]. For that reason, Finland, Sweden, Denmark, Austria, and Germany showed a research and development expenditure over the $3 \%$ of their GDP, while Romania, Cyprus, Latvia, and Bulgaria were under the $1 \%$ of their GDP.

\section{Conclusions}

The aim of this paper was to assess the sustainable performance of EU countries through a cross-country comparison. This result can help procurers to decide what sustainability categories to consider in the bidding processes, as well as to assist in having an orientation regarding their level of importance. Five environmental categories and eight social categories were established as the sustainability criteria to be included in public procurement of the construction industry. To analyze the sustainable performance of the $28 \mathrm{EU}$ countries, national indicators were used. Eighteen environmental and 24 social indicators were selected from statistical databases. After a discrimination analysis and a correlation analysis to assess the suitability of the dataset, the Promethee method was performed to rank the countries. Finally, a cluster analysis was undertaken to extract conclusions about the overall performance of these countries. The results highlight differences in sustainability performance between the most economically developed EU countries with regard to the less well-off ones. In this sense, two groups of countries were identified to address sustainability. The first cluster consisted of the wealthiest countries (north-west axis): Germany, Austria, Czech Republic, Belgium, Netherlands, Luxembourg, Ireland, the United Kingdom, Denmark, Sweden, and Finland. These countries showed good performances on social aspects; however, they need to improve the results in terms of environmental sustainability. The second cluster was made up of the economically least developed countries (south-east axis): Slovak Republic, Italy, Poland, Cyprus, Slovenia, France, Spain, Portugal, Croatia, Greece, Estonia, Malta, Hungary, Lithuania, Bulgaria, Romania, and Latvia. These countries are characterized by being significantly behind in achieving the EU vision for sustainable European development, as these showed the lowest results in terms of social sustainability. Therefore, the results highlight the main categories to be addressed in each European country; however, due to the ongoing financial crisis, public authorities are faced with making challenging budgets. Thus, new innovative construction materials, technologies, and processes should be promoted to improve energy and environmental performance on a cost-effective manner. On the other hand, to promote the use of social and environmental considerations in public procurement procedures, the transposition of the EU directives into national legislation is not sufficient and legal frameworks must be complemented with actions to increase knowledge and improve capacity among public authorities and companies. In this respect, once the main environmental and social categories to be included in public procurement of each country have been identified, the indicators defined by the Joint Research Centre and the European Commission's Science and Knowledge Service in their procurement practice guidance documents can provide valuable assistance to procure sustainable infrastructures.

Regarding the limitations of this study, the assessment of the sustainability performance of EU countries depends on public datasets at the macro level. Thus, the availability and quality of national indicators can influence the results. In the case of the dataset collected, the indicators featured are characterized by very high availability and their quality is regularly monitored. On the other hand, the search for national indicators was consistent; however, it is possible that some indicators were not adequately identified and, therefore, were excluded from the search results. This fact is important since it can be expected that a different selection of social and environmental indicators could lead to a different cluster of countries.

Future research is needed to define quantitative indicators and weighting methodologies to assess environmental and social sustainability in public procurement, as well as developing industry-based national indicators for assessing sustainability performance in the construction industry. 
Author Contributions: This paper represents a result of teamwork. All of the authors jointly designed the research methodology. L.M.-D., M.A.-M., and T.G.-S. analyzed the results. All of the authors jointly worked on the discussion. L.M.-D., M.A.-M., and T.G.-S. drafted the manuscript. Finally, E.P. reviewed and edited the manuscript. All authors have read and agreed to the published version of the manuscript.

Funding: This research was funded by the Spanish Ministry of Economy and Competitiveness, grant number BIA2017-85098-R and the Valencian Regional Government, grant number GV/2018//085.

Conflicts of Interest: The authors declare no conflict of interest.

\section{References}

1. Penadés-Plà, V.; García-Segura, T.; Martí, J.V.; Yepes, V. An optimization-LCA of a prestressed concrete precast bridge. Sustainability 2018, 10, 685. [CrossRef]

2. Xia, B.; Chen, Q.; Xu, Y.; Li, M.; Jin, X. Design-build contractor selection for public sustainable buildings. J. Manag. Eng. 2015, 31, 04014070. [CrossRef]

3. Aguilar-Morocho, M.; Montalbán-Domingo, L.; García-Segura, T.; Pellicer, E. Estudio de las necesidades sociales y ambientales para la selección de criterios sostenibles en la contratación de obra pública en España. In Proceedings of the International Congress on Project Management and Engineering-CIPID 2019, Málaga, Spain, 10-12 July 2019; Universidad de Málaga: Málaga, Spain, 2019.

4. Ruparathna, R.; Hewage, K. Sustainable procurement in the canadian construction industry: Current practices, drivers and opportunities. J. Clean. Prod. 2015, 109, 305-314. [CrossRef]

5. Kornevs, M.; Kringos, N.; Meijer, S. A Research Agenda for Green Procurement of Infrastructures. In Proceedings of the 2014 International Conference on Engineering, Technology and Innovation (ICE), Bergamo, Italy, 23-25 June 2014.

6. Kahlenborn, W.; Moser, C.; Frijdal, J.; Essig, M. Strategic use of Public Procurement in Europe-Final Report to the European Commission MARKT/2010/02/C; Adelphi: Berlin, Germany, 2011.

7. Directive 2004/18/EC, 2004/18/ECC. Directive of the European Parliament and of the Council of 31 March 2004 on the coordination of procedures for the award of public works contracts, public supply contracts and public service contracts. Off. J. Eur. Union 2004, 18, 156-235.

8. Testa, F.; Grappio, P.; Gusmerotti, N.M.; Iraldo, F.; Frey, M. Examining green public procurement using content analysis: Existing difficulties for procurers and useful recommendations. Environ. Dev. Sustain. 2016, 18, 197-219. [CrossRef]

9. The European Commission. Buying Green! A Handbook on Green Public Procurement; European Union: Brussels, Belgium, 2016; ISBN 9789279568480.

10. Sanchez-Graells, A. Public procurement and 'core' human rights: A sketch of the EU legal framework. In Public Procurement and Human Rights; Edward Elgar Publishing: Cheltenham, UK, 2018.

11. European Commission. Buying Social. A Guide to Taking Account of Social Considerations in Public Procurement; Publications Office of the European Union: Luxembourg, 2010; ISBN 9789279187384.

12. IHRB. Protecting Rights by Purchasing Right: The Human Rights Provisions, Opportunities and Limitations Under the 2014 EU Public Procurement Directives; Institute for Human Rights and Business (IHRB): London, UK, 2015; ISBN 9781467324205.

13. European Commission European commission. Directive 2014/24/EU of the European Parliament and of the Council of 26 February 2014 On Public Procurement and Repealing Directive 2004/18/EC. Available online: https://eur-lex.europa.eu/legal-content/EN/TXT/PDF/?uri=CELEX:32014L0024\&rid=1 (accessed on 8 June 2020).

14. Montalbán-Domingo, L.; García-Segura, T.; Sanz, M.A.; Pellicer, E. Social sustainability criteria in public-works procurement: An international perspective. J. Clean. Prod. 2018, 198, 1355-1371. [CrossRef]

15. The European Commission. Buying for Social Impact. Good Practice from Around the EU; Toland, J., Ed.; Publications Office of the European Union: Luxembourg, 2019; ISBN 9789292028114.

16. Montalbán-Domingo, L.; García-Segura, T.; Sanz, M.A.; Pellicer, E. Social Sustainability in Delivery and Procurement of Public Construction Contracts. J. Manag. Eng. 2019, 35, 04018065. [CrossRef]

17. Sourani, A.; Sohail, M. Barriers to addressing sustainable construction in public procurement strategies. Proc. Inst. Civ. Eng. Eng. Sustain. 2011, 164, 229-237. [CrossRef] 
18. Ugwu, O.O.; Kumaraswamy, M.M.; Wong, A.; Ng, S.T. Sustainability appraisal in infrastructure projects (SUSAIP) Part 1. Development of indicators and computational methods. Autom. Constr. 2006, 15, $239-251$. [CrossRef]

19. Shi, Y.; Ge, X.; Yuan, X.; Wang, Q.; Kellett, J.; Li, F.; Ba, K. An integrated indicator system and evaluation model for regional sustainable development. Sustainability 2019, 11, 2183. [CrossRef]

20. Szopik-Depczyńska, K.; Cheba, K.; Bak, I.; Stajniak, M.; Simboli, A.; Ioppolo, G. The study of relationship in a hierarchical structure of EU sustainable development indicators. Ecol. Indic. 2018, 90, 120-131. [CrossRef]

21. Yli-Viikari, A.; Hietala-Koivu, R.; Huusela-Veistola, E.; Hyvönen, T.; Perälä, P.; Turtola, E. Evaluating agri-environmental indicators (AEIs)-Use and limitations of international indicators at national level. Ecol. Indic. 2007, 7, 150-163. [CrossRef]

22. Antanasijević, D.; Pocajt, V.; Ristić, M.; Perić-Grujić, A. A differential multi-criteria analysis for the assessment of sustainability performance of European countries: Beyond country ranking. J. Clean. Prod. 2017, 165, 1-19. [CrossRef]

23. Phillis, Y.A.; Kouikoglou, V.S.; Verdugo, C. Urban sustainability assessment and ranking of cities. Comput. Environ. Urban Syst. 2017, 64, 254-265. [CrossRef]

24. Widomski, M.K.; Gleń, P.; Łagód, G.; Jaromin-Gleń, K.M. Sustainable development of one of the poorest province of the European Union: Lublin voivodeship, Poland - attempt of assessment. Probl. Sustain. Dev. 2015, 10, 137-149.

25. Illankoon, I.M.C.S.; Tam, V.W.Y.T.; Le, K.N. Environmental, economic, and social parameters in international green building rating tools. J. Prof. Issues Eng. Educ. Pract. 2017, 143, 05016010. [CrossRef]

26. Cook, D.; Saviolidis, N.M.; Davíðsdóttir, B.; Jóhannsdóttir, L.; Ólafsson, S. Measuring countries' environmental sustainability performance-The development of a nation-specific indicator set. Ecol. Indic. 2017, 74, 463-478. [CrossRef]

27. Walker, H.; Brammer, S. The relationship between sustainable procurement and e-procurement in the public sector. Int. J. Prod. Econ. 2012, 140, 256-268. [CrossRef]

28. Varnäs, A.; Balfors, B.; Faith-ell, C. Environmental consideration in procurement of construction contracts: Current practice, problems and opportunities in green procurement in the Swedish construction industry. J. Clean. Prod. 2009, 17, 1214-1222. [CrossRef]

29. Anthonissen, J.; Van Troyen, D.; Johan, B.; Van Den Bergh, W. Using carbon dioxide emissions as a criterion to award road construction projects: A pilot case in Flanders Joke. J. Clean. Prod. 2015, 102, 96-102. [CrossRef]

30. Testa, F.; Annunziata, E.; Iraldo, F.; Frey, M. Drawbacks and opportunities of green public procurement: An effective tool for sustainable production. J. Clean. Prod. 2016, 112, 1893-1900. [CrossRef]

31. Ekener, E.; Hansson, J.; Larsson, A.; Peck, P. Developing life cycle sustainability assessment methodology by applying values-based sustainability weighting - Tested on biomass based and fossil transportation fuels. J. Clean. Prod. 2018, 181, 337-351. [CrossRef]

32. Carnevalli, J.A.; Miguel, P.C. Review, analysis and classification of the literature on QFD-Types of research, difficulties and benefits. Int. J. Prod. Econ. 2008, 114, 737-754. [CrossRef]

33. Rodríguez-lópez, F.; Fernández-sánchez, G. Challenges for Sustainability Assessment by Indicators. Leadersh. Manag. Eng. 2011, 11, 321-325. [CrossRef]

34. Fernández-Sánchez, G. Sustainability Assessment Approaches: Towards a Global Sustainability Development. In Global Sustainable Development and Renewable Energy Systems; IGI Global: Hershey, PA, USA, 2012; pp. 172-187. ISBN 9781466616257.

35. Dasgupta, S.; Tam, E.K.L. Indicators and framework for assessing sustainable infrastructure. Can. J. Civ. Eng. 2005, 32, 30-44. [CrossRef]

36. Dobrovolskiien, N.; Tamošiluniene, R. An Index to Measure Sustainability of a Business Project in the Construction Industry: Lithuanian Case. Sustainability 2016, 8, 14. [CrossRef]

37. Shen, L.; Wu, Y.; Zhang, X. Key assessment indicators for the sustainability of infrastructure projects. J. Constr. Eng. Manag. 2011, 137, 441-451. [CrossRef]

38. ISI. ENVISION Rating System For Sustainable Infrastructure; Institute for Sustainable Infrastructure: Washington, DC, USA, 2015.

39. Ugwu, O.O.; Haupt, T.C. Key performance indicators and assessment methods for infrastructure sustainability-A South African construction industry perspective. Build. Environ. 2007, 42, 665-680. [CrossRef] 
40. FHWA. INVEST-Sustainable Highways Self-Evaluation Tool; U.S. Department of Transportation, Federal Highway Administration: Washington, DC, USA, 2012.

41. Muench, S.T.; Anderson, J.; Hatfield, J.; Koester, J.; Söderlund, M. Greenroads Manual v1. 5; Anderson, J., Weiland, C., Muench, S., Eds.; University of Washington: Seattle, WA, USA, 2011; Volume 1.5.

42. Jeon, C.M.; Amekudzi, A. Addressing sustainability in transportation systems: Definitions, indicators, and metrics. J. Infrastruct. Syst. 2005, 11, 31-50. [CrossRef]

43. Wu, Z.; Zhang, X.; Wu, M. Mitigating construction dust pollution: State of the art and the way forward. J. Clean. Prod. 2016, 112, 1658-1666. [CrossRef]

44. CEEQUAL. The Assessment and Awards Scheme for Improving Part 1: Maintenance; CEEQUAL: Watford, UK, 2011.

45. Lim, S.K. Framework and Processes for Enhancing Sustainability Deliverables in Australian road Infrastructure Projects. Ph.D. Thesis, Queensland University of Technology, Brisbane, Australia, 2009.

46. Beckwith, P.; Farrington, L.; Ainsworth, A.; Fox, J.; Napier, L.; Ball, S.; Steadman, R.; Edmond, G.; Tomlinson, P. The Assessment and Awards Scheme for Improving Part 1: Maintenance; CEEQUAL: Watford, UK, 2011.

47. DEFRA. Procuring the Future. In Sustainable Procurement National Action Plan: Recommendations from the Sustainable Procurement Task Force; Department for Environment, Food and Rural Affairs: London, UK, 2006.

48. Azapagic, A. Developing a framework for sustainable development indicators for the mining and minerals industry. J. Clean. Prod. 2004, 12, 639-662. [CrossRef]

49. IDOT. I-LAST. Illinois-Livable and Sustainable Transportation Rating System and Guide; Illinois Department of Transportation (IDOT): Springfield, IL, USA, 2012.

50. Bajjou, M.S.; Chafi, A.; Ennadi, A.; El Hammoumi, M. The practical relationships between lean construction tools and sustainable development: A literature review. J. Eng. Sci. Technol. Rev. 2017, 10, 170-177. [CrossRef]

51. Fuentes-Bargues, J.; González-Cruz, M.; González-Gaya, C. Environmental criteria in the spanish public works procurement process. Int. J. Environ. Res. Public Health 2017, 14, 204. [CrossRef] [PubMed]

52. NYSDOT. GreenLITES Project Design Certification Program; New York State Department of Transportation: New York, NY, USA, 2009.

53. Faith-Ell, C.; Balfors, B.; Folkeson, L. The application of environmental requirements in Swedish road maintenance contracts. J. Clean. Prod. 2006, 14, 163-171. [CrossRef]

54. European Commission. EU Green Public Procurement Criteria for Road Design, Construction and Maintenance; Joint Research Centre, European Comission: Brussels, Belgium, 2016.

55. Sarkis, J.; Meade, L.M.; Presley, A.R. Incorporating sustainability into contractor evaluation and team formation in the built environment. J. Clean. Prod. 2012, 31, 40-53. [CrossRef]

56. Valdes-Vasquez, R.; Klotz, L.E. Social sustainability considerations during planning and design: Framework of processes for construction projects. J. Constr. Eng. Manag. 2013, 139, 80-89. [CrossRef]

57. CEEQUAL. The Assessment and Awards Scheme for Improving Sustainability in Civil Engineering and the Public Realm; CEEQUAL Ltd.: Watford, UK, 2010.

58. Whang, S.-W.; Kim, S. Balanced sustainable implementation in the construction industry: The perspective of Korean contractors. Energy Build. 2015, 96, 76-85. [CrossRef]

59. Mccrudden, C. Using public procurement to achieve social outcomes. Nat. Resour. Forum 2004, $28,257-267$. [CrossRef]

60. GRI. Sustainability Reporting Guidelines; Global Reporting Initiative: Amsterdam, The Netherlands, 2011.

61. Pellicer, E.; Sanz, M.A.; Esmaeili, B.; Molenaar, K.R. Exploration of team integration in spanish multifamily residential building construction. J. Manag. Eng. 2016, 32, 05016012. [CrossRef]

62. Shiau, T.-A.; Chuen-Yu, J.-K. Developing an indicator system for measuring the social sustainability of offshore wind power farms. Sustainability 2016, 8, 470. [CrossRef]

63. UNEP. Guidelines for Social Life Cycle Assessment of Products; United Nations Environment Programme: Paris, France, 2009; ISBN 9789280730210.

64. Purcell, P.; Bruen, M.; O'Sullivan, J.; Cocchiglia, L.; Kelly-Quinn, M. Water quality monitoring during the construction of the M3 motorway in Ireland. Water Environ. J. 2012, 26, 175-183. [CrossRef]

65. Popovic, T.; Barbosa-Póvoa, A.; Kraslawski, A.; Carvalho, A. Quantitative indicators for social sustainability assessment of supply chains. J. Clean. Prod. 2018, 180, 748-768. [CrossRef]

66. Rahdari, A.H.; Rostamy, A.A.A. Designing a general set of sustainability indicators at the corporate level. J. Clean. Prod. 2015, 108, 757-771. [CrossRef] 
67. Abdel-Raheem, M.; Ramsbottom, C. Factors Affecting Social Sustainability in Highway Projects in Missouri. Procedia Eng. 2016, 145, 548-555. [CrossRef]

68. GRI. GRI 403: Occupational Health and Safety; Global Reporting Initiative: Amsterdam, The Netherlands, 2018.

69. Landorf, C. Evaluating social sustainability in historic urban environments. Int. J. Herit. Stud. 2011, 17, 463-477. [CrossRef]

70. Petersen, D.; Kadefors, A. Social procurement and employment requirements in construction. In Proceedings of the 32nd Annual ARCOM Conference, ARCOM 2016, Manchester, UK, 5-7 September 2016; Volume 2, pp. 997-1006.

71. GRI. GRI 404: Training and Education; Global Reporting Initiative: Amsterdam, The Netherlands, 2016; ISBN 978-90-8866-056-6.

72. Kenny, C. Construction, Corruption, and Developing Countries; World Bank Policy Research Working Paper 4271; World Bank Group: Washington, DC, USA, 2007.

73. Akenroye, T.O. An appraisal of the use of social criteria in public procurement in Nigeria. J. Public Procure. 2013, 13, 364-397. [CrossRef]

74. GRI. GRI 414: Supplier Social Assessment; Global Reporting Initiative: Amsterdam, The Netherlands, 2016.

75. Sierra, L.A.; Pellicer, E.; Yepes, V. Social sustainability in the lifecycle of chilean public infrastructure. J. Constr. Eng. Manag. 2016, 142, 05015020. [CrossRef]

76. Xiahou, X.; Tang, Y.; Yuan, J.; Chang, T.; Liu, P.; Li, Q. Evaluating social performance of construction projects: An empirical study. Sustainability 2018, 10, 2329. [CrossRef]

77. CIRIA. Sustainable Construction Company Indicators; Construction Industry Research and Information Association (CIRIA): London, UK, 2001; ISBN 0860175634.

78. United Nations. Guidance on Corporate Responsibility Indicators in Annual Reports; United Nations Conference on Trade and Development: New York, NY, USA, 2008; ISBN 9789211127409.

79. DVFA. Key Performance Indicators for Environmental, Social and Governance Issues; DVFA, Society of Investment Professionals in Germany: Dreieich, Germany, 2009.

80. Eurostat Eurostat Database. Available online: https://ec.europa.eu/eurostat/data/database (accessed on 2 October 2017).

81. OECD. OECD Data. Available online: https://data.oecd.org/ (accessed on 2 October 2017).

82. SDG. The sustainable development goals (SDGs) index. Available online: http://sdgindex.org/ (accessed on 2 October 2017).

83. ILO. International Labour Organization Statistics and Datablases. Available online: https://www.ilo.org/ global/statistics-and-databases/lang--en/index.htm (accessed on 2 October 2017).

84. UNCSD. United Nations System. Chief Executives Board for Coordination. Statistics. Available online: https://www.unsceb.org/content/statistics (accessed on 2 October 2017).

85. Puig, M.; Wooldridge, C.; Darbra, R.M. Identification and selection of environmental performance indicators for sustainable port development. Mar. Pollut. Bull. 2014, 81, 124-130. [CrossRef]

86. Nardo, M.; Saisana, M.; Saltelli, A.; Tarantola, S. Tools for Composite Indicators Building; Institute for the Protection and Security of the Citizen Econometrics and Statistical Support to Antifraud Unit I-21020: Ispra, Italy, 2005; ISBN 1471-0072.

87. Joint Research Centre-European Commission. Handbook on Contructing Composite Indicators: Methodology and User Guide; Joint Research Centre (JRC) of the European Commission: Brussels, Belgium; OECD: Paris, France, 2008; ISBN 9789264043459.

88. World Bank World Bank Open Data. Available online: https://data.worldbank.org/ (accessed on 2 October 2017).

89. Dos Santos, S.F.; Brandi, H.S. Model framework to construct a single aggregate sustainability indicator: An application to the biodiesel supply chain. Clean Technol. Environ. Policy 2015, 17, 1963-1973. [CrossRef]

90. Młodak, A. On the construction of an aggregated measure of the development of interval data. Comput. Stat. 2013, 29, 895-929. [CrossRef]

91. Field, A. Discovering Statistics Using IBM SPSS Statistics; SAGE Publications: Los Angeles, CA, USA, 2013; ISBN 9781847879066.

92. Hair, J.F.; Black, W.C.; Babin, B.J.; Anderson, R.E. Multivariate Data Analysis; Pearson New International edition Seventh edition; Pearson: Harlow, UK, 2014. 
93. Kazançoğlu, Y.; Özbiltekin, M.; Özkan-Özen, Y.D. Sustainability benchmarking for logistics center location decision: An example from an emerging country. Manag. Environ. Qual. An Int. J. 2019. [CrossRef]

94. Pohekar, S.D.; Ramachandran, M. Application of multi-criteria decision making to sustainable energy planning - A review. Renew. Sustain. Energy Rev. 2004, 8, 365-381. [CrossRef]

95. Neofytou, H.; Nikas, A.; Doukas, H. Sustainable energy transition readiness: A multicriteria assessment index. Renew. Sustain. Energy Rev. 2020, 131, 109988. [CrossRef]

96. Behzadian, M.; Kazemzadeh, R.B.; Albadvi, A.; Aghdasi, M. PROMETHEE: A comprehensive literature review on methodologies and applications. Eur. J. Oper. Res. 2010, 200, 198-215. [CrossRef]

97. Rehman, A.U.; Abidi, M.H.; Umer, U.; Usmani, Y.S. Multi-criteria decision-making approach for selecting wind energy power plant locations. Sustainability 2019, 11, 6112. [CrossRef]

98. González, F.; Martín, F.; Martín, F.; Novo-corti, I. Sustainability and the Spanish port system. Analysis of the relationship between economic and environmental indicators. MPB 2016, 113, 232-239. [CrossRef]

99. García-Segura, T.; Montalbán-Domingo, L.; Sanz, M.A.; Lozano-Torró, A. Sustainable Decision-Making Module: Application to Public Procurement. J. Civ. Eng. Educ. 2020, 146, 04020004. [CrossRef]

100. Iles, D.; Ryall, P. How can the United Kingdom construction industry implement sustainable procurement strategies? In Proceedings of the 32nd Annual ARCOM Conference, Manchester, UK, 5-7 September 2016; pp. 1121-1130.

101. Phillis, A.; Grigoroudis, E.; Kouikoglou, V.S. Assessing national energy sustainability using multiple criteria decesion anaysis. Int. J. Sustain. Dev. World. Ecol. 2020, 1-18. [CrossRef]

102. Report, J.; The, O.F.; Committee, E.; Committee, S.P. 2020 STRATEGY; Publications Office of the European Union: Luxembourg, 2020; ISBN 9789276119814.

103. European Environmental Agency. Trends and Projections in Europe 2019_Tracking Progress towards Europe's Climate and Energy Targets; European Environmental Agency: Copenhagen, Denmark, 2019.

104. Kristensen, P.; Whalley, C.; Zal, F.N.N.; Christiansen, T. European Waters Assessment of Status and Pressures 2018; European Environmental Agency: Copenhagen, Denmark, 2018; ISBN 0203938607.

105. Eurostat. Sustainable Development in the European Union-Monitoring Report on Progress towards the SDGs in an EU Context; Eurostat: Luxemburg, 2019.

106. Council, E. Joint Employment As adopted by the EPSCO Council; European Union: Brussel, Belgium, 2019.

107. Oswald, D.; Sherratt, F.; Smith, S. Problems with safety observation reporting: A construction industry case study. Saf. Sci. 2018, 107, 35-45. [CrossRef]

108. Pelzman, J. Science, Technology and Innovation in MENA; World Scientific: Singapore, 2012; ISBN 9789279269226. 